\title{
A léböjtkúrák és az atípusos evészavarok lehetséges kapcsolata
}

\author{
Kvalitatín elótanulmány
}

\author{
Bóna Enikő ${ }^{1}$ - Forgács Attila dr. ${ }^{2}$ - Túry Ferenc dr. ${ }^{1}$ \\ ${ }^{1}$ Semmelweis Egyetem, Általános Orvostudományi Kar, Magatartástudományi Intézet, Budapest \\ ${ }^{2}$ Eötvös Loránd Tudományegyetem, Pedagógiai és Pszichológiai Intézet, Budapest
}

\begin{abstract}
Bevezetés és célkitüzés: A kórképpé minősítés előszobájában két, említésre méltó evési viselkedés is van: a DSM-5-ben nemspecifikus evészavarként feltüntetett purgálózavar és az egészségesétel-függőségnek fordított orthorexia nervosa. Célunk annak leírása, hogy ezek miként figyelhetők meg a léböjttáborokban, amelyek alternatív egészségmegőrző trendként igen népszerüek napjainkban.

Módszer: Az első szerző két országos léböjttáborban többterepú etnográfiai megfigyeléssel rögzítette adatait. A gyújtése során készült terepnapló, jegyzetek és interjúk alapján mutatjuk be az evészavartünetek motívumait.

Eredmények: A tábor legfőbb motívuma a „méregtelenítés”. A szilárd táplálék nélkülözése s ezáltal igen alacsony kalóriabevitel és fizikai aktivitás során bekövetkező gyors testi változásokat a mérgek távozásának tudják be. A léböjttábor résztvevői beiktatták mindennapos rutinjukba a szándékos hashajtást is, amelyhez pozitív konnotációk társulnak, és a holisztikus szemlélet jegyében az „elengedés” és „megújulás” lelki folyamataihoz kötik. A szimbólumok használata az élettani folyamatokkal kapcsolatban erősen észlelhető volt. A vízvesztésből adódó gyors fogyás lendülete, a tiszta étkezés iránti vágy és az ezoterikus-önsegítő kultúrából kölcsönzött „önjutalmazás” is gyakori motívumok. Az újratáplálásból adódó komplikációk miatt eddig két halálesetet tartanak számon a táborszervezők.

Következtetések: Mind a purgálózavarra, mind az orthorexia nervosára találhatók jól beazonosítható leírások. Ez azt mutatja, hogy a klinikumon kívüli környezetben is komoly a valószínűsége olyan evési magatartások intézményesítésének, amelyek az egészségre veszélyesek. A „méregtelenítés” ugyanis nemcsak fiziológiailag lehet káros, de hosszú távú mentális segítségnyújtásra sincs bizonyíték. Megoldásként javasoljuk az egészséges életmódról és étkezésről szóló tévhitekre irányuló megfelelő egészségkommunikációs terv kidolgozását és a pszichoterápiás lehetőségek népszerüsítését.
\end{abstract}

Orv Hetil. 2018; 159(28): 1153-1157.

Kulcsszavak: evészavarok, böjtölés, orvosi antropológia

\section{Potential relationship between juice cleanse diets and eating disorders}

\section{A qualitative pilot study}

Introduction and aim: There are two notable eating behaviors that are not far from having their own category as a mental disorder: the purging disorder, that is already among the DSM-5 non-specific eating disorders, and orthorexia nervosa, when a person is fixating too much on healthy foods. Our purpose is to describe how these can be observed in recreational juice cleanse camps, which are very popular today as an alternative health trend.

Method: The first author recorded her data during multisited ethnographic observations in two Hungarian juice cleanse camps. Based on the diary logs, notes and interviews collected, we will present the motives of eating anomalies that the participants had shown.

Results: The main motive of the camp is "detoxification". The lack of solid food, drastically low calorie intake and lots of physical activity will bring an inevitable change in the body, that is interpreted as toxins leaving the body. Participants have also included deliberate use of laxatives in their everyday routines, with which they associate positive connotations and are linked to the spiritual processes of "letting it go" and "renewal" in the spirit of a holistic approach. The use of symbols in the physiological processes was highly noticeable. Rapid weight loss due to diuresis, the desire for "clean" meals, and "self-rewarding" borrowed from the esoteric-self-help culture are also common motives. Due to the refeeding complications, so far two deaths have been reported by camp organizers. 
Conclusions: Both purging disorder and orthorexia nervosa can be well-identified in our observations. This shows that also in the non-clinical environment, there is an institutionalization of eating habits that are dangerous to the health. This "detox" is not only physiologically harmful, but it is not proved to provide long-term help in mental health either. As a solution, we advocate developing an appropriate health communication plan for misconceptions about healthy lifestyle and eating, and also a promotion of psychotherapeutic opportunities.

Keywords: eating disorders, fasting, medical anthropology

Bóna E, Forgács A, Túry F. [Potential relationship between juice cleanse diets and eating disorders. A qualitative pilot study]. Orv Hetil. 2018; 159(28): 1153-1157.

(Beérkezett: 2018. február 15.; elfogadva: 2018. március 9.)

\section{Rövidítések}

$\mathrm{BED}=($ binge eating disorder $)$ falászavar; $\mathrm{DSM}=($ diagnostic and statistical manual of mental disorders) mentális betegségek diagnosztikai és statisztikai kézikönyve; $\mathrm{ON}=$ (orthorexia nervosa) egészségesétel-függőség

A pszichiátriai zavarok legújabb nozológiai rendszere, a DSM-5 szerint jelenleg hat elkülöníthető evészavart tartunk számon. Az anorexia nervosa és a bulimia nervosa mellé a falászavar, más néven binge eating disorder (BED), az elkerülő/restriktív táplálékfelvételi zavar, a pica és a ruminatiós zavar is bekerült [1]. A klasszifikációban találhatók még egyéb nemspecifikus vagy atípusos zavarok (például éjszakai evés szindróma vagy purgálózavar).

A kórképpé minősítés előszobájában két jelenség is van. Az orthorexia nervosa $(\mathrm{ON})$ egészségesétel-függőséget jelent [2, 3]. Az ebben szenvedők arra törekszenek, hogy csak egészséges (illetve annak tartott) táplálékokat vegyenek magukhoz. A másik a már említett purgálózavar [4]. Ez a BED ellentéte: falásrohamok nincsenek, purgáló viselkedésformák viszont jellemzőek. A falási, purgálási szokásokat impulzív tünetként tartják számon [5], míg az étel minőségére fordított túlzó figyelmet a kényszeres viselkedés spektrumába sorolják [6]. E kapcsolódásokat az evészavarok spektrumszemlélete fogja össze, amely az egyes formák hátterében tapasztalható dinamikát a „kompulzív-impulzív spektrum” mentén írja le [5], s itt helyezhetjük el az ON-t és purgálózavart is mint új lehetséges evészavart.

Környezetünk hatalmas változáson ment keresztül az ON első említése, de már a legutóbbi DSM kiadása óta is. Míg az elmúlt évtizedben a színes magazinokban található tanácsadás evészavart kiváltó kockázatáról készültek a felmérések [7-9], napjainkban már a közösségi média vette át ennek a helyét. Az információáradat megsokszorozta az egészséges életmód iránti érdeklődést [10], de számos kutatás alátámasztja az énképre és a testképre ható negatív befolyást is $[11,12]$. Megfigyelhetjük, ahogy táplálkozási és életvezetési hiedelemrendsze- rek irányulnak az egészségességre, és ideológiává fejlődnek. Ezt a tendenciát már közel négy évtizede felismerték, és egészségizmusnak keresztelték el [13].

Nem meglepő, hogy az információs társadalom egyik központi kérdése lett a táplálkozás és az egészség, ugyanis egyre több kutatási eredmény születik a tápanyagok, élelmiszerek élettani hatásáról. A dietoterápiás protokollok jól tükrözik ezeket az eredményeket, és számos autoimmun betegség tünetmentesítésére, legyőzésére rendkívül jó hatással lehetnek különféle szigorú étrendek [14-16], illetve a nutrigenetikában tett előrelépések is jelentősek [17].

A különböző egészségkommunikációs fórumokon azonban a leghitelesebb kutatások eredményei is eltorzulhatnak az egészségizmus lencséjén keresztül, megzavarva a befogadót [18]. Marketingcélok által vezérelt divatirányzatok, a fitneszipar és a bulvársajtó leegyszerüsített, áltudományos, néhol akár sarlatán keretbe helyezve juttatja el az egyébként értékes információt a tömegekhez. Eleget téve az egészségmegőrzés normáinak, egyes személyek félreértelmezhetik, és többet ártanak egészségüknek, mint fordítva. Több esettanulmány is beszámol speciális diétákból eredő, kórházi kezelést igénylő tápanyaghiányról [19-22].

Az alternatív egészségmegőrző trendek egyike a léböjtkúrák alkalmazása. Közleményünkben betekintést nyújtunk a léböjtölés köré szerveződő bentlakásos táborok alapvetéseibe és a jelenség világába. Megfigyelésünk eredményei alapján ezen közösségekben találkozik a két fent említett, kóros evési viselkedés: az ON és a purgálózavar. Elemzésünkben az itt végzett purgáló tevékenységek és ételválasztások archaikus jelentéseit, illetve a testi és a lelki egészségre gyakorolt negatív hatásaikat vizsgáljuk.

\section{Módszer}

2017 novemberében és 2018 januárjában az első szerző (B. E.) táborlakóként tapasztalatszerzés és adatgyưjtés céljából két országosan meghirdetett léböjttáborba látogatott. Többterepű etnográfiai megfigyelés készült. 
A helyi vizsgálatok eredményeit összehasonlítottuk: a részt vevő megfigyelés részletes terepnaplója, a jotting (gyors jegyzetelés az antropológiai adatgyuujtés során) és az adatközlőkkel $(\mathrm{n}=12)$ készült interjúszövegek voltak a fö forrásaink. A strukturálatlan érdeklődést és terepfelmérést követte a strukturált szakasz: ebben a helyszínen felvetődött kérdésekkel, illetve prekoncepciók tisztázásával készültek az interjúk, amelyekhez a résztvevők adatközlőként önkéntesen járultak hozzá. A kiválasztás feltétele a tábor közösségéhez tartozás és a léböjt véghezvitele volt. A tizenkét interjúból három olyan személyekkel készült, akik a tábor létrehozásában aktívan részt vettek - az ő esetükben kibővített interjúra került sor, amelyben a szervezés motivációira is rákérdeztünk. A jelen tanulmány nem tartalmazza azonban ezek módszeres elemzését; csupán ismertető és figyelemfelhívó jelleggel fókuszál az evészavartünetek motívumaira.

\section{Eredmények}

Annak ellenére, hogy a biomedicina álláspontja alapján egyre többen és gyakrabban megcáfolják a léböjtkúrák hatékonyságát, a módszer a mai napig igen népszerú eszköze sokak fogyókúrájának, egészségmegőrzési törekvéseinek. Hívei elsősorban tisztító hatást tulajdonítanak neki: a szilárd táplálék nélkülözése, s ezáltal igen alacsony kalóriabevitel és fizikai aktivitás során bekövetkező gyors testi változásokat a mérgek távozásának tudják be. Interjúk során elmondták a résztvevők, hogy a hétköznapokban nem követik ezt a táplálkozási szigort: változatosan étkeznek, s volt, aki kifejezetten „hedonista” életmódot folytat, melyet itt „ki tud egyenlíteni”.

A purgálás rituáléja állandó motívum. Naponta fordulnak elő az étrendben hashajtó oldatok, levek, melyek hatásáról a résztvevőket megfelelően tájékoztatják. Az ezután kiváltódó hasmenéses tünetekre használják szinonímaként a „méregtelenítés”, „tisztulás”, „béltisztítás”, „felgyorsult anyagcsere” szavakat. Láthatjuk, hogy ezek pozitív konnotációk, annak ellenére, hogy kóros emésztési folyamatról van szó. Azt hangsúlyozzák, hogy a „bélrendszer tisztasága” az előfeltétele a méregtelenítésnek, a „toxinoktól való szabadulás” pedig meg kell, hogy történjen annak érdekében, hogy a kívánt „megújulás” elinduljon. Ezen táborok és elvonulások célja ugyanis az újratervezés, és a holisztikus szemlélet jegyében a testi és a lelki folyamatok összekötése magától értetődő. Az „elengedés” motívuma szintén fontos. Ezt is a hasmenéssel kötik össze: akinek nem hat eléggé a hashajtó, az valószínúleg rumináló, elengedésre képtelen személyiség. A szimbólumok használata az élettani folyamatokkal kapcsolatban erősen észlelhető volt.

A fogyókúrás célok is igen gyakoriak. Megfigyeléseink alapján az egyik tábor a minél gyorsabb fogyást túzte ki célul, és a résztvevők többsége ebben definiálta az önbecsülés alapját. Ehhez tökéletes eszköz lehet egy ilyen tábor, ugyanis a vízvesztés és az extrém kalóriadeficit elengedhetetlenül a testsúly hirtelen csökkenéséhez vezet.
A résztvevők elmondása alapján ez a lendület nagy segítség egy nagyobb fogyás megindításához, az önbizalom megérkezéséhez (hiszen véghez tudta vinni a kúrát), és ezek következményeként a lelki nyugalomhoz is.

A drasztikus fogyás és vízhajtás azonban komoly kockázatokkal is járhat. Két haláleset köthető a fogyókúratámogató tábor utáni rendkívül veszélyes visszatáplálási időszakhoz. Az egyik esetben a hasnyálmirigy enzimtermelésének zavarai következtében halt meg egy férfi, a másik pedig a sóháztartás felborulásához köthetô szívleállás volt.

Az önsegítő irodalom alapját képező félreértelmezett pozitív pszichológia terminusai is gyakran felfedezhetők a léböjttáborokban. Önmagunk jutalmazását eltúlozva az „énido” prioritása, a „pozitív gondolatok” és a „kényeztetés" szlogenjei szélsőséges cselekedetekre és gondolkodásra ösztönzik a résztvevőket. Ez abban nyilvánult meg, hogy az éhezés, purgálás nehézségeit azonnal kompenzálni „kell” rituálékkal (masszázs, kényeztetés, jutalmazás, „elengedésterápia”, „boldogságterápia”), hogy meglegyen az „egyensúly”.

\section{Megbeszélés}

A terepnapló-kivonatokból és az interjúkból levont tanulságok arra mutatnak, hogy a purgálózavar, de néhol az ON tünetei is feltünnek a léböjttáborozók viselkedésében. A napi hashajtózás és az egészségesétel-függőség ugyanakkor nincs ilyen mértékben jelen a mindennapokban, ezért a kórképpé minősítés ennyi adatból nehézkes és nem lehetséges. Érdemes azonban felfigyelni arra, hogy a klinikumon kívüli környezetben is komoly a valószínüsége olyan evési magatartások intézményesítésének, amelyek az egészségre veszélyesek. A drasztikus ételmegvonás utáni újratáplálásra kórházi protokollok születnek [23], nem véletlenül, hiszen a rosszul visszavezetett étkezés halálos szövődményekkel járhat [24]. A táborok után előforduló ritka halálesetek különösen tragikusak, hiszen egészségmegőrzés céljából végezték a purgálást.

A böjtöt a tisztaság iránti archaikus vágyakkal és az ehhez kapcsolódó ősi tudással kötik össze [25]. Ennek fontossága már a Bibliában is fellelhető: olvashatók ugyanis étkezési tiltások, amelyek akkor a betegségek higiéniai ismeretének hiányában mégis helyénvalónak bizonyultak. A tehertől való megkönnyebbülés böjt általi elérése sem új fogalom. Az étel hosszabb-rövidebb ideig tartó megvonása a mai napig is rendszeres rituálé különféle népeknél, vallásokban [26]. Napjainkban azonban ugyanennek a törekvésnek a legkézenfekvőbb eszköze a „méregtelenítés”, amelyet a fáradt XXI. századi ember, távol a munkahelyi stressztől és családi problémáktól, valódi kiszakadásként él meg. A folyékony táplálékok bevitele és a purgálás teremti meg a tisztaság érzetét. A „clean eating” [27] gondolatvilága hasonló: az egészségizmus ideológiája megálljt parancsol az egészségtelen ételeknek, ami rendkívül hasznos, azonban az egyén fe- 
lelősségét eltúlozva káros hiedelemrendszerek és a törzsi gondolkodás kialakulását is ösztönzi.

A léböjttábor szellemisége az önsegítésnek a túlzó pozitivitással kapcsolatos hiedelmeivel torzítja azt az egyébként fontos törekvést, miszerint törődni kell a testi és mentális egészséggel. A táborban részt vevő személyek ugyanis a kellemetlen, szenvedést okozó érzelmektől és testérzetektől való megszabadulásra a hashajtás szimbolikáját és a jutalmazó tevékenységeket használják egyidejúleg. Ez a narratíva azért káros, mert a purgálás komoly szövődményekkel járhat, s ez az önsértő viselkedés látszólag pozitív érzelmekkel (jutalommal) zárul. Az elmúlt években a pozitív pszichológia második hullámának nevezett iskola foglalkozott annak kritikájával, hogy a negatív gondolatok, érzelmek eltávolítását támogató mozgalmak uralják a választ kereső modern ember gondolatait. Állításuk és kutatásaik szerint csak az élettel együtt járó szenvedések tudatosításával lesz igazán pozitív a gondolatvilágunk, egyfajta szintézisként egyesítve a pozitívat és a negatívat [28]. Az egzisztencialista pszichoterápiás megközelítéshez hasonlóan olyan nézeteket vallanak, miszerint az embernek szembe kell néznie szenvedéseivel, és értelemkereső, a saját sorsát uraló életet kell élnie. Erre reflektálva tekintünk mellékvágányként a léböjttáborokra, mert a negatívtól való megszabaduláson, a túlzó boldogságkeresésen van a hangsúly. Ehelyett megoldás lehetne a potenciális résztvevők felé irányuló megfelelő egészségkommunikáció és pszichoedukáció, melyben a purgálás tévhitjellegéről kapnának hiteles információt. A „méregtelenítés” ugyanis nemcsak fiziológiailag lehet káros, de mentálisan sem nyújt hoszszú távú segítséget.

\section{Limitációk}

Közleményünk előtanulmányként tárja fel azt a területet, amely az atípusos evészavarok jövőbeli alakulása és kezelése során fontos ismereteket hordoz.

A kvalitatív kutatások és esettanulmányok statisztikai módszerekkel alátámasztva fontos eszközök az említett jelenségek felderítésére. A DSM-en kívüli mentális zavarokat azonban igen nehéz kutatni, mert etikai vetületük is van. Ha egy kórosnak látszó jelenséget kórképpé akarunk minősíteni, figyelembe kell venni, hogy mindennapos, racionális, egészségmegőrző ambíciókat ne patologizáljunk. Óvatos munkát igényel az egyes esetek figyelembevétele. Ha az $\mathrm{ON}$ diagnózisát állapítjuk meg olyan személy esetében, aki bizonyos tápanyagokra túlérzékenyen reagál, és úgy dönt, hogy nem veszi ezeket magához, akkor a patologizáló stigma csapdájába esünk - még akkor is, ha ez megszállott diétázásként jelenik meg. Lehetséges, hogy számára egy orthorexiásnak minősített étrend az egyetlen megoldás az életminőséghez. A további kutatásokban ez megfontolandó szempont.

\section{Következtetés}

A léböjtkúrák és -táborok egyre nagyobb népszerüségnek örvendenek, résztvevőik azonban nem veszik figyelembe az egészségügyi kockázatokat. Annak ellenére, hogy a böjtölés gyökerei az ember tisztaság iránti archaikus igényéből indulnak, a bemutatott kúrák inkább maladaptívnak minősülnek. A túlzott vízvesztés és az újratáplálási szindróma helytelen kezelése halálos lehet. Ez az írás figyelemfelkeltés, hiszen egyre több hasonló jelenség figyelhető meg az evés és a táplálkozási szokások körében. A legfőbb teendő tehát a boldogságot kereső XXI. századi egyén helyénvaló edukációja: mind az igényes egészségkommunikációról, mind a pszichoterápiák lehetőségeiről.

Anyagi támogatás: A közlemény megírása anyagi támogatásban nem részesült.

Szerzôi munkamegosztás: B. E.: Részt vevő megfigyelőként, az adatok rögzítése majd kiértékelése, a cikk megírása. T. F., F. A.: Szakértői részvétel a problémafelvetésben, az eredmények értékelésében. A cikk végleges változatát mindhárom szerző elolvasta és jóváhagyta.

Érdekeltségek: A szerzőknek nincsenek érdekeltségeik.

Etikai engedély: A jelen interjús kutatást a TUKEB a 3563-1. számú vizsgálat részleteként elfogadta.

\section{Irodalom}

[1] American Psychiatric Association. Diagnostic and statistical manual of mental disorders ( 5 th edn.). American Psychiatric Publishing, Arlington, VA, 2013.

[2] Bratman S. Orthorexia vs. theories of healthy eating. Eat Weight Disord. 2017; 22: 381-385.

[3] Original essay on orthorexia. Available from: http://www.orthorexia.com/original-orthorexia-essay/ [accessed: February 28, 2016].

[4] Keel PK, Haedt A, Edler C. Purging disorder: an ominous variant of bulimia nervosa? Int J Eat Disord. 2005; 38: 191-199.

[5] Szalai TD. The relationship of attachment features and multiimpulsive symptoms in eating disorders. [A kötődési jellemzók és multiimpulzív tünetek kapcsolata az evészavarokban.] Orv Hetil. 2017; 158: 1058-1066. [Hungarian]

[6] Varga M, Dudás K, Túry F. Orthorexia nervosa - Health food addiction. In: Demetrovics Z. (ed.) Basics of addictology, IV. [Az orthorexia nervosa - egészségesétel-függőség. In: Demetrovics Z. (szerk.) Az addiktológia alapjai. IV kötet.] ELTE Eötvös Kiadó, Budapest, 2007; pp. 447-458. [Hungarian]

[7] Harrison K, Taylor LD, Marske AL. Women's and men's eating behavior following exposure to ideal-body images and text. Commun Res. 2006; 33: 507-529.

[8] Van den Berg P, Neumark-Sztainer D, Hannan PJ, et al. Is dieting advice from magazines helpful or harmful? Five-year associations with weight-control behaviors and psychological outcomes in adolescents. Pediatrics 2007; 119: 30-37.

[9] Roy, SC. 'Taking charge of your health': discourses of responsibility in English-Canadian women's magazines. Sociol Health Illn. 2008; 30: 463-477. 
[10] Health Online 2013. PewResearch Internet Project. Available from: http://www.pewinternet.org/files/old-media/Files/Reports/PIP_HealthOnline.pdf [accessed: February 28, 2016].

[11] Tiggemann, M, Zaccardo M. "Exercise to be fit, not skinny.": The effect of fitspiration imagery on women's body image. Body Image 2015; 15: 61-67.

[12] Turner PG, Lefevre CE. Instagram use is linked to increased symptoms of orthorexia nervosa. Eat Weight Disord. 2017; 22: 277-284.

[13] Crawford R. Healthism and the medicalization of everyday life. Int J Health Serv. 1980; 10: 365-388.

[14] Hallböök T, Jib S, Maudsley S, et al. The effects of the ketogenic diet on behavior and cognition. Epilepsy Res. 2012; 100: 304-309.

[15] Lange KW, Lange KM, Makulska-Gertruda E, et al. Ketogenic diets and Alzheimer's disease. Food Sci Hum Wellness 2017; 6: $1-9$.

[16] Null G, Pennesi L. Diet and lifestyle intervention on chronic moderate to severe depression and anxiety and other chronic conditions. Complement Ther Clin Pract. 2017; 29: 189-193.

[17] Sarkadi NE, Martos É. Present and future of genotype-based personalized nutrition. [A genetikaiprofil-alapú, személyre szabott táplálkozás jelene és jövője.] Orv Hetil. 2014; 155: 771777. [Hungarian]

[18] Rangel C, Dukeshire S, MacDonald L. Diet and anxiety. An exploration into the orthorexic society. Appetite 2012; 58: 124132.

[19] Tóth A, Aradi G, Várallyay Gy, et al. Wernicke's encephalopathy induced by the use of diet pills and unbalanced diet. [Wernickeencephalopathia kialakulása fogyasztótabletta használata és kiegyensúlyozatlan diéta következtében.] Orv Hetil. 2014; 155: 469-474. [Hungarian]

[20] Nauta K, Toxopeus K, Eekhoff EM. Malnutrition due to an extremely 'healthy' diet; a new eating disorder? Ned Tijdschr Geneeskd. 2016; 160: A9164.
[21] Moroze RM, Dunn TM, Holland JC, et al. Microthinking about micronutrients: A case of transition from obsessions about healthy eating to near-fatal "orthorexia nervosa" and proposed diagnostic criteria. Psychosomatics 2015; 56: 397-403.

[22] Park SW, Kim JY, Go GJ, et al. Orthorexia nervosa with hyponatremia, subcutaneous emphysema, pneumomediastimum, pneumothorax, and pancytopenia. Electrolyte Blood Press. 2011; 9: 32-37.

[23] Maginot TR, Kumar MM, Shiels J, et al. Outcomes of an inpatient refeeding protocol in youth with anorexia nervosa: Rady Children's Hospital San Diego/University of California, San Diego. J Eat Disord. 2017; 5: 1-5.

[24] Matthews KL, Capra SM, Palmer MA. Throw caution to the wind: is refeeding syndrome really a cause of death in acute care? Eur J Clin Nutr. 2018; 72: 93-98.

[25] Forgács A. Psychology of eating. [Az evés lélektana.] Akadémiai Kiadó, Budapest, 2004. [Hungarian]

[26] Lukács L, Kézdy A. Religion and eating disorders: Significance of the BPSS model. In: Túry F, Pászthy B. (eds.) Eating disorders and body image disorders. [Vallás és evészavarok: A biopszichoszociális-spirituális modell jelentősége. In: Túry F, Pászthy B. (szerk.) Evészavarok és testképzavarok.] Pro Die, Budapest, 2008; pp. 329-340. [Hungarian]

[27] McCartney M. Clean eating and the cult of healthism. BMJ 2016; 354: i4095.

[28] Wong PT. Positive psychology 2.0: Towards a balanced interactive model of the good life. Can Psychol. 2011; 52: 69-81.

(Bóna Enikő, Budapest, Nagyvárad tér 4., 1089 e-mail: bona.eniko@phd.semmelweis-univ.hu)

\section{„Post fructum purum vinum." (Salernoi iskola) (Gyümölcs után tiszta bort kell inni.)}

A cikk a Creative Commons Attribution-NonCommercial 4.0 International License (https://creativecommons.org/licenses/by-nc/4.0) feltételei szerint publikált Open Access közlemény, melynek szellemében a cikk nem kereskedelmi célból bármilyen médiumban szabadon felhasználható, megosztható és újraközölhető, feltéve, hogy az eredeti szerző és a közlés helye, illetve a CC License linkje és az esetlegesen végrehajtott módositások feltüntetésre kerülnek. 